\section{KRITERIJUMI I PROCEDURE ZA UGRADNJU FIZIČKIH PREPREKA ZA USPORAVANJE SAOBRAĆAJA}

dr Vuk Bogdanović, dipl. inž. saobraćaja

Univerzitet u Novom Sadu, Fakultet tehničkih nauka, vuk@uns.ac.rs

dr Valentina Basarić, dipl. inž. saobraćaja

Univerzitet u Novom Sadu, Fakultet tehničkih nauka, plast@uns.ac.rs

dr Jelena Mitrović Simić, dipl. inž. saobraćaja

Univerzitet u Novom Sadu, Fakultet tehničkih nauka, mjelena@uns.ac.rs

dr Nenad Ruškić, dipl. inž. saobraćaja

Univerzitet u Novom Sadu, Fakultet tehničkih nauka, nruskic@uns.ac.rs

dr Zoran Papić, dipl. inž. saobraćaja

Univerzitet u Novom Sadu, Fakultet tehničkih nauka, njele@uns.ac.rs

Nenad Saulić, master dipl. inž. saobraćaja

Univerzitet u Novom Sadu, Fakultet tehničkih nauka, n.saulic@uns.ac.rs

Nemanja Garunović, master dipl. inž. saobraćaja

Univerzitet u Novom Sadu, Fakultet tehničkih nauka, garunovic@uns.ac.rs

Stručni rad

Rezime: Motorna vozila omogućavaju brzinu kretanja koja često nije u skladu sa uslovima odvijanja saobraćaja. Iz tog razloga, mere za usporavanjem vozila, primenom usporivača, primenjuju se više od jednog veka. Dosadašnja iskustva su pokazala da je u okviru postavljenih zakonskih okvira korisno i opravdano da gradovi, odnosno lokalne zajednice, definišu kriterijume $i$ procedure za upotrebu usporivača, izbor lokacija, pokretanje procedura za njihovu ugradnju i način donošenja odluka. U ovom radu, na osnovu istraživanja koja su sprovedena u Novom Sadu, biće definisani kriterijumi za izgradnju usporivača, vrednovanje kriterijuma, postupak izbora vrste usporivača u zavisnosti od svrhe i karakteristika lokacije i kriterijumi za izbor mikrolokacija u okviru izabrane lokacije. Cilj rada je definisanje kriterijuma $i$ procedura koji bi, u skladu sa važećim propisima, odgovorili na potrebe Grada Novog Sada i drugih lokalnih zajednica u ovoj oblasti.

Ključne reči: usporavanje, mere, brzina, kriterijumi, vrednovanje

\section{THE CRITERIA AND PROCEDURES FOR INSTALLATION OF TRAFFIC CALMING DEVICES}

Vuk Bogdanović, Ph.D. T.E.

University of Novi Sad, Faculty of Technical Sciences, vuk@uns.ac.rs Valentina Basarić, Ph.D. T.E.

University of Novi Sad, Faculty of Technical Sciences, plast@uns.ac.rs Jelena Mitrović Simić, Ph.D. T.E.

University of Novi Sad, Faculty of Technical Sciences, mjelena@uns.ac.rs

Nenad Ruškić, Ph.D. T.E.

University of Novi Sad, Faculty of Technical Sciences, nruskic@uns.ac.rs

Zoran Papić, Ph.D. T.E.

University of Novi Sad, Faculty of Technical Sciences, njele@uns.ac.rs Nenad Saulić, M.Sc. T.E.

n.saulic@uns.ac.rs

Nemanja Garunović, M.Sc. T.E.

University of Novi Sad, Faculty of Technical Sciences, garunovic@uns.ac.rs
Professional paper Abstract: Motor vehicles provide speeds that often don't comply with the traffic conditions. For this reason, the different measures have been applied for more than one century in order to regulate the driving speed. World experiences have shown that it is useful and justified for cities or local communities to define the criteria and procedures for the use of traffic calming devices, the choice of locations, the launching of procedures for their installation and decision making process. This paper presents the criteria for the installation of traffic calming devices, the evaluation of criteria, the procedure for choosing a type of devices depending on the purpose and characteristics of the site and the criteria for the selection of micro-location within the selected location. The aim of the paper is to define criteria and procedures that will respond to the needs of the City of Novi Sad and the other local communities in this area in accordance with current regulations.

Key words: calming, measures, speed, criteria, evaluation

\section{UVOD}

Za potrebe usporavanja saobraćaja koriste se različite vrste usporivača i drugih tehničkih sredstva kojim se vozači primoravaju na kretanje manjom brzinom, odnosno koji služe za kontrolu brzine kretanja motornih vozila na pojedinim delovima putne i ulične mreže. Osnovna podela usporivača saobraćaja je na sredstva za upozoravanje i fizičke prepreke koje se izgrađuju na kolovozu i koje fizički onemogućavaju kretanje vozila brzinama koje su veće od definisane. Fizičke prepreke se u zavisnosti od karakteristika dele na horizontalne i vertikalne. Povodi za upotrebu usporivača su različiti. Najčešće je to potreba da se kroz smanjenje brzine utiče na smanjenje broja saobraćajnih nezgoda, smanjenje nivoa buke, a veoma često se koriste i kao mera za ograničavanje ili otežavanje pristupa, odnosno kao mera za demotivaciju vozača da se kreću pojedinim delovima ulične mreže.

Iskustva upotrebe usporivača u svetu su uglavnom pozitivna, u situacijama kada je oblast njihove upotrebe uređena [1,2]. Međutim, da bi se ova oblast potpuno uredila, neophodno je, u skladu sa potrebama i karakteristikama saobraćajnog sistema, planova, ciljeva i strategije razvoja lokalnih zajednica, definisati kriterijume za upotrebu usporivača. $\mathrm{Na}$ takav način stvara se osnov da se kroz objetivnu proceduru po unapred definisanim kriterijumima definišu lokacije na kojima je upotreba usporivača neophodna, odnosno da se njihova upotreba uredi i ograniči. Dakle, u okviru postavljenih zakonskih okvira, korisno je i opravdano da lokalne zajednice definišu kriterijume i procedure za upotrebu usporivača, izbor lokacija, pokretanje procedura za njihovu ugradnju i način donošenja odluka. 
$\mathrm{Na}$ teritoriji Grada Novog Sada u dosadašnjem periodu postavljeno je više vrsta različitih usporivača. $\mathrm{Na}$ početku su usporivači postavljani stihijski, na inicijativu građana, povod je najčešće bila incidenta situacija, najčešće saobraćajna nezgoda, a svrha postavljanja smanjenje brzine kretanja vozila. Usporivači nisu postavljani prema unapred pripremljenom planu ili prema definisanim kriterijumima, već prema trenutnim inicijativama javnosti ili nekih institucija. Pri tom nisu pravljene dublje analize u smislu stvarnih potreba, odnosno istraživanja u vezi vrste usporivača koji bi na pravi način odgovorili potrebama.

Kako razlozi ugradnje usporivača mogu biti različiti, javila se potreba da se u Gradu Novom Sadu definišu kriterijumi za izgradnju usporivača, postupak izbora vrste usporivača u zavisnosti od svrhe i karakteristika lokacije i kriterijumi za izbor mikrolokacija u okviru izabrane lokacije. $U$ radu će biti prikazani kriterijumi koji su definisani u skladu sa sprovedenim istraživanjem na karakterističnim lokacijama i u skladu sa svetskim iskustvima. Kriterijumi su rezultat studije „Primena prinudnih usporivača saobraćaja na teritoriji Grada Novog Sada sa posebnim osvrtom na metodologiju i uslove za implementaciju mera“" [3].

\section{KRITERIJUMI I PROCEDURE ZA UGRADNJU USPORIVAČA - SVETSKA ISKUSTVA}

lako usporivači predstavljaju praktično najefikasniji način upravljanja brzinama, oni se ne mogu postaviti na svakom mestu i na svakom putu i ulici, čak ni u uslovima ugrožene bezbednosti saobraćaja. Naime, usporivači generalno utiču na smanjenje komfora vožnje, povećanja buke i vibracija u zoni njihove primene, rastresanja tereta, usporavanje ili onemogućavanje pristupa vozilima hitnih službi itd. Iz tog razloga, mnoge države, ali i lokalne zajednice, su kreirale priručnike u kojima su dati kriterijumi za postavljanje usporivača na putnoj i uličnoj mreži.

Najveći broj kriterijuma za ugradnju usporivača nastao je u Sjedinjenim Američkim Državama (SAD) $[4,5,6,7]$ gde su vremenom postali jedna od najpopularnijih mera za umirivanje saobraćaja iz dva osnovna razloga: efikasni su u smanjivanju brzine, a troškovi ugradnje i održavanja su minimalni. U SAD pravni akti vezani za upotrebu usporivača na putnoj $i$ uličnoj mreži uglavnom se donose na nivou saveznih država. Međutim, u situaciji kada na državnom nivou ne postoje odgovarajući propisi, njih donose gradovi, odnosno lokalne zajednice.

Prema preporukama ITE (Institute of Transporation Engineers), pored dimenzija i karakteristika vertikalnih izbočina, definisano je postojanje planova za kontrolu brzine koje treba da imaju sve institucije koje se bave ugradnjom usporivača.
Planovi ili podržavaju postavljanje usporivača kao široko prihvaćeno rešenje za smanjenje brzine i/ili obima saobraćaja ili bezuslovno odbijaju njihovu upotrebu. Prilikom utvrđivanja da li posmatrana lokacija ima neophodne saobraćajno - tehničke uslove za ugradnju fizičkih prepreka za smanjenje brzine, mogu se javiti sledeća ograničenja za njihovu upotrebu: ulice koje opslužuje autobuski prevoz, ulice sa dnevnim obimom saobraćaja iznad unapred definisanih granica, sabirne ulice, putevi van naselja [8].

Pri analizi mogućnosti primene usporivača primenom kriterijuma definisanih u Kaliforniji (SAD), važno je sa jedne strane uzeti u obzir operativne karakteristike ulice i karakteristike kolovoza sa druge strane [5]. Ulica mora biti klasifikovana kao lokalna, sa pratećim elementima stambenog bloka i pogodna za ugradnju usporivača. Nakon izbora dimenzija i oblika platforme koji su definisani standardima u ovoj oblasti primenjuje se kriterijum prioriteta. Prioritetne lokacije se definišu na osnovu izmerenih prekoračenja brzine, broja i posledica saobraćajnih nezgoda i blizine škola, parkova i institucija.

Prema važećim kriterijumima u državi Vašington (SAD) zahtev za ugradnju fizičkih prepreka može biti jedino razmatran na ulicama unutar stambenih blokova. Kriterijumima su precizno navedene dimenzije platformi, kao i pozicioniranje na uličnoj mreži. Definisana je takođe i procedura ugradnje fizičkih prepreka koja podrazumeva većinsku saglasnost lokalnog stanovništva, kao i procedura uklanjanja fizičkih prepreka [9].

Procedura ugradnje fizičkih prepreka u Njujorku (SAD) počinje od pisanog zahteva građana ili udruženja građana za postavljanjem usporivača. Fizička prepreka se može postaviti isključivo na ulicama drugog reda, ali uz obaveznu analizu uslova odvijanja saobraćaja na lokaciji koja je predviđena za postavljanje usporivača. Postavljanje fizičkih prepreka se uvek izvodi po prioritetima koji zavise od izmerene brzine, utvrđene veličine zahteva za protokom, kao i izveštaja o saobraćajnim nezgodama. Postavljeni usporivači se nadgledaju u periodu od šest meseci do godinu dana. Ako se pojave problemi koji stvaraju nebezbedne situacije zbog nepravilnog postavljanja ili održavanja, usporivač se uklanja [9].

Prema priručniku koji je izdat od strane DDOT (District Department of Transportation) vertikalne platforme mogu biti postavljene nakon prijema zahteva od strane građana, a zahtev podržava najmanje $75 \%$ domaćinstava koja se nalaze u stambenom bloku ili u delu ulice za koji se zahteva postavljanje prepreka. 
Ulice moraju da ispunjavaju određene kriterijume (ulica mora biti lokalna, ne sme biti na tranzitnom putu, niti sme biti primarna saobraćajnica za vozila hitnih službi, podužni nagib kolovoza ne sme prelaziti $8 \%$ itd.). Nakon podnošenja zahteva DDOT sprovodi vrednovanje ispunjenosti uslova pre postavljanja prepreka radi utvrđivanja pogodnosti predložene lokacije i usaglašenosti sa kriterijumima. DDOT može naložiti uklanjanje ili modifikovanje usporivača ili primenu drugih mera za umirivanje saobraćaja, ako postojeće mere ne ispunjavaju očekivane ciljeve ili ako dovode do pojave nebezbednih situacija u saobraćaju [10].

U okviru priručnika za grad Sacshe u državi Teksas (SAD) određeno je da ulice moraju ispuniti određene opšte karakteristike (ograničenje brzine od $30 \mathrm{mph}$ ili manje, saobraćajno opterećenje od 500 voz/h, dvotračne ulice itd.), kao i geometrijeske karakteristike (preglednost, put ne sme biti u krivini, uzdužni nagib ne sme biti veći od 5\% itd.) [4].

U propisima „The Highways (Road Humps) Regulations" definisana je upotreba i ugradnja vertikalnih izbočina na državnim putevima $u$ Engleskoj i Velsu. U okviru ove odredbe navedeno je da je potrebno izvršiti konsultacije sa policijom, lokalnom službom, vatrogasnom službom, službom hitne pomoći i reprezentativnim predstavnicima organizacija koje koriste put [11].

Osnovni kriterijumi koji se tiču širine i visine usporivača koji su postavljeni u Italiji zavise od postavljenog ograničenja brzine. Vertikalne izbočine mogu biti postavljene na ulice unutar stambenog bloka, na privatnim ili javnim parkiralištima, ali pozicioniranje ovih usporivača na ulicama koje su uključene u rutu kretanja vozila hitnih službi je zabranjeno. Svaki usporivač čiji je zadatak smanjenje brzine mora biti postavljen u skladu sa propisanim elementima i moraju biti napravljeni od kaučuka (gume) i plastičnih materijala, dok je upotreba betona ograničena na ulice $u$ kojima je postavljeno ograničenje brzine do $30 \mathrm{~km} / \mathrm{h}$.

U Republici Srbiji primena tehničkih sredstava za usporavanje saobraćaja, vrste, njihov izgled, tehničke karakteristike i način obeležavanja definisani su u okviru važećih propisa koje donosi Vlada Republike Srbije i ministarstvo nadležno za poslove saobraćaja (Zakon o bezbednosti saobraćaja, Pravilnik o tehničkim sredstvima za usporavanje saobraćaja na putu, Pravilnik o saobraćajnoj signalizaciji).

Pored zakonskih regulativa $u$ okvir referentnih normativa, a kao dokumenti nižeg ranga, mogu se svrstati i različita tehnička uputstva, priručnici i smernice koji se odnose na primenu sredstava za usporavanje saobraćaja.
Kao takve objavljene su smernice „Sredstava i mere za usporavanje saobraćaja“, kao deo Priručnika za projektovanje puteva u Republici Srbiji, izdatim od strane JP „Putevi Srbije“. Bliže i detaljnije definisanje tehničkih uslova koje moraju da ispune tehnička sredstva za usporavanje saobraćaja definisana su u okviru nacionalnog SRPS standard - kataloška grupa U.C1.

\section{PREDLOG KRITERIJUMA ZA UGRADNJU FIZIČKIH PREPREKA ZA USPORAVANJE SAOBRAĆAJA U NOVOM SADU}

U cilju definisanja kriterijuma za ugradnju fizičkih prepreka u Gradu Novom Sadu potrebno je u obzir uzeti način pokretanja inicijative za ugradnju, procedure i kriterijume koji se primenjuju u svetu, efekte koji se postižu ugradnjom u zavisnosti od vrste usporivača, kao i zakonsku regulativu i pravne akte koji su aktuelni u našoj zemlji.

U skladu sa iskustvima u svetu, predlog za postavljanje usporivača može da potiče od strane građana, ukoliko oni smatraju da je bezbednost u nekoj ulici ili gradskoj zoni ugrožena, da je povećan nivo buke ili da više od $20 \%$ vozila ukupnog saobraćajnog toka ulicu koristi kao alternativni pravac za obilazak gradskih arterija. Uz predlog građana dostavlja se saglasnost najmanje $75 \%$ stanara ulice koja je predložena za postavljanje usporivača.

Predlagač može biti i Gradska uprava za saobraćaj ukoliko se utvrdi da se na nekoj deonici ostvaruju značajno veće brzine od dozvoljenih, odnosno ukoliko se najmanje $50 \%$ vozača kreće brzinom koja je za najmanje $10 \mathrm{~km} / \mathrm{h}$ veća od dozvoljene. Razlozi za postavljanje usporivača mogu se argumentovati i parametrima bezbednosti saobraćaja.

Preporučuje se da se na putnoj i uličnoj mreži Grada Novog Sada usporivači ne postavljaju na:

1. Državnim putevima

2. Gradskim arterijama

3. Sabirnim ulicama na kojima je PGDS veći od $5.000 \mathrm{voz} / \mathrm{dan}$

4. Ulicama sa ograničenjem brzine većim od 50 $\mathrm{km} / \mathrm{h}$

5. Ulicama koje predstavljaju uobičajene rute kretanja vozila hitnih službi (vozila hitne pomoći i vatrogasnih vozila)

6. Ulicama na trasama linija javnog prevoza

7. Ulicama sa saobraćajnim tokom u čijoj strukturi je prisutno više od $5 \%$ teretnih vozila

8. Ulicama na kojima je PGDS manji od 200 voz/dan

9. Ulicama sa uzdužnim nagibom kolovoza većim od $5 \%$ 
Ukoliko se javi potreba za usporavanjem saobraćaja na ulicama koje pripadaju gore navedenim kategorijama, pribegava se drugim merama usporavanja saobraćaja (semaforizacija, izgradnja kružnih raskrsnica, kontrola brzine itd.).

Usporivači se izuzetno mogu postaviti i na prethodno navedenim kategorijama puteva ili ulica, odnosno na deonicama državnog puta, kolektorskim ulicama, ulicama koje predstavljaju putanje kretanja vozila hitnih službi ili se nalaze na trasi linije javnog prevoza, ukoliko su ispunjeni kriterijumi koji važe za ulice gde je dozvoljeno postavljanje usporivača, uz posebno obrazloženje predlagača. Posebno obrazloženje predlagača mora biti argumentovano dokazima o potrebi postavljanja usporivača, koji se mogu odnositi na bezbednost saobraćaja ili povećan nivo buke. $U$ takvim slučajevima potrebno je koristiti usporivače koji ne zahvataju ceo profil kolovoza saobraćajnice, odnosno:

- veštačke izbočine iz više delova

- veštačke izbočine tipa jastuk

- veštačke izbočine u vidu gumenih diskova.

Ulice na koje se postavljaju usporivači, odnosno fizičke prepreke za usporavanje saobraćaja, moraju imati sledeće karakteristike:

1. Ulica pripada kategoriji pristupne ulice ili sabirne ulice na kojoj je PGDS manji od 5.000 voz/dan

2. Kolovozni zastor je izrađen od asfalta ili druge savremene podloge

3. Na ulici važi opšte ograničenje brzine za naselja od $50 \mathrm{~km} / \mathrm{h}$ ili manje

4. Preglednost duž ulice iznosi najmanje $60 \mathrm{~m}$

5. Podužni nagib kolovoza najmanje $60 \mathrm{~m}$ pre usporivača je manji od $5 \%$

6. Dužina ulice iznosi najmanje $150 \mathrm{~m}$

7. PGDS je veći od $200 \mathrm{voz} / \mathrm{dan}$.

$\mathrm{Da}$ bi se postigla svrha, odnosno da bi se postavljanjem usporivača postigli željeni efekti, potrebno je definisati svrhu postavljanja usporivača, koja može biti:

- Smanjenje brzine na lokaciji ili delu ulice

- Smanjenje nivoa buke

- Preusmeravanje saobraćaja na okolne ulice.

Ukoliko je potrebno smanjiti brzinu vozila samo na užoj lokaciji koriste se pojedinačni usporivači, što obezbeđuje kratkotrajan efekat usporavanja i smanjenja brzine. Sa druge strane, ukoliko se želi postići kontinualno smanjenje brzine na čitavoj deonici ili ukoliko se želi izvršiti preusmeravanje vozila na okolne ulice, onda se koristi niz uzastopnih usporivača. Ukoliko se postavljaju u nizu, usporivači se postavljaju na međusobnoj udaljenosti od 50-100 m. Na potezu dugom 300 do $500 \mathrm{~m}$ predlog je da se postave najmanje tri usporivača. Prvi usporivač u seriji bi trebalo da se postavi na mestu gde vozači ne mogu da dostignu najveću brzinu. Za ekstremno smanjenje brzina vozila preporučuje se postavljanje dva ili tri usporivača na kratkom odstojanju $(0,5$ do 1 $\mathrm{m})$.

Mikrolokacija izabranog usporivača treba da ima sledeće karakteristike:

- Preglednost nije ograničena vertikalnim i/ili horizontalnim krivinama, što omogućava uočavanje usporivača na rastojanju od najmanje $60 \mathrm{~m}$.

- Pozicija usporivača ne ometa odvodnjavanje vode sa kolovoza.

- Usporivač se ne nalazi iznad energetskih, telekomunikacionih, vodovodnih i kanalizacionih šahtova, ventila ili vatrogasnih hidranta.

- Mikrolokacija usporivača ne nalazi se naspram raskrsnica, pristupnih puteva, prolaza i kolskih prilaza.

- Mikrolokacija usporivača se nalazi naspram ili u zoni svetlosnog snopa ulične svetiljke.

- Usporivač je udaljen najmanje $8 \mathrm{~m}$ od pešačkog prelaza.

- Usporivač je udaljen najviše 20 m od pešačkog prelaza.

Materijal od kojeg se izrađuju fizičke prepreke za usporavanje saobraćaja može biti od gume, plastike ili od materijala kojim se izrađuju putevi. U cilju bolje uočljivosti preporučljivo je da jedan deo površine usporivača bude prekriven retroreflektujućim materijalom.

Za izbor tipa usporivača potrebno je uzeti u obzir karakteristiku lokacije na kojoj je potrebno postaviti usporivač, odnosno da li se radi o jednosmernoj ili dvosmernoj ulici, izdvojenom pešačkom prelazu ili raskrsnici, poprečni profil ulice, karakteristike horizontalne trase, svrhu postavljanja i karakteristike saobraćajnog toka. Za izbor tipa usporivača potrebno je koristiti Tabele 1, 2, 3 i 4.

\subsection{Vrednovanje kriterijuma za izbor lokacije usporivača}

Ukoliko postoji više lokacija u lokalnoj zajednici na kojima je potrebno postaviti usporivače potrebno je definisati prioritete za njihovo postavljanje. Preporuka je da se vrednovanje izvrši prema postupku koji je dat Tabeli 5.

Lokacije koje su pogodne za postavljanje fizičkih prepreka za usporavanje saobraćaja moraju imati više od $55 \%$ od maksimalnog broja bodova po predloženim kriterijumima. 
Tabela 1. Kriterijumi za izbor tipa usporivača na jednosmernoj ulici

\begin{tabular}{|c|c|c|c|c|c|c|c|c|c|c|c|c|c|c|c|c|c|}
\hline & \multicolumn{3}{|c|}{$\begin{array}{l}\text { Profil ulice sa } \\
\text { trotoarom }\end{array}$} & \multicolumn{3}{|c|}{$\begin{array}{l}\text { Profil ulice bez } \\
\text { trotoara }\end{array}$} & \multicolumn{3}{|c|}{$\begin{array}{l}\text { Karakteristike } \\
\text { trase }\end{array}$} & \multicolumn{3}{|c|}{$\begin{array}{l}\text { Svrha } \\
\text { postavljanja }\end{array}$} & \multicolumn{4}{|c|}{$\begin{array}{l}\text { Karakteristike } \\
\text { saobraćajnog toka }\end{array}$} \\
\hline & & 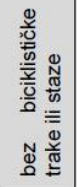 & 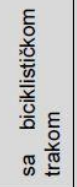 & 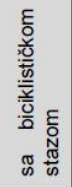 & 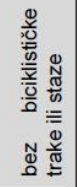 & 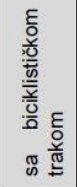 & 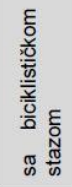 & 疍 & 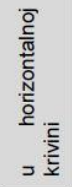 & 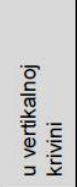 & 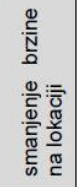 & 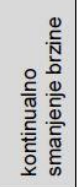 & 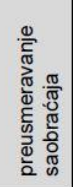 & $\begin{array}{l}\frac{\pi}{N} \mathscr{~} \\
\stackrel{0}{>}\end{array}$ & 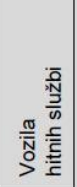 & 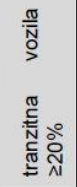 & 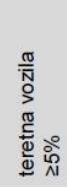 \\
\hline \multirow{4}{*}{ 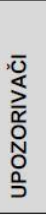 } & $\begin{array}{l}\text { Optičke } \\
\text { linije }\end{array}$ & $x$ & $x$ & $x$ & $x$ & $x$ & $x$ & & & & & & & & & & \\
\hline & $\begin{array}{l}\text { Zvučne } \\
\text { trake }\end{array}$ & $x$ & $x$ & $x$ & $x$ & $x$ & $x$ & & & & $x$ & $x$ & & & & & \\
\hline & $\begin{array}{l}\text { Dragon } \\
\text { teeth }\end{array}$ & $x$ & $x$ & $x$ & $x$ & $x$ & $x$ & $x$ & & & $x$ & & & & & & \\
\hline & $\begin{array}{l}\text { Obojeni } \\
\text { kolovoz }\end{array}$ & $x$ & $x$ & $x$ & $x$ & $x$ & $x$ & & & & & & & $x$ & $x$ & $x$ & $\mathrm{x}$ \\
\hline \multirow{9}{*}{ 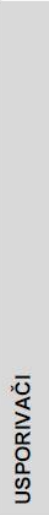 } & \multirow{2}{*}{$\begin{array}{l}\text { Permanentne } \\
\text { veštačke izbočine } \\
\text { Veštačke izbočine } \\
\text { iz dva ili tri dela }\end{array}$} & & $x$ & $x$ & & $x$ & $x$ & $x$ & & & $x$ & & $x$ & & & $x$ & \\
\hline & & $x$ & $x$ & $x$ & $x$ & $x$ & $x$ & $x$ & & & $x$ & & $x$ & $x$ & $x$ & $\mathrm{x}$ & $x$ \\
\hline & \multirow{3}{*}{$\begin{array}{l}\text { Veštačka } \\
\text { izbočina - jastuk } \\
\text { Gumeni } \\
\text { diskovi } \\
\text { Izdignute } \\
\text { Platforme } \\
\end{array}$} & $x$ & $x$ & $x$ & $x$ & $x$ & $x$ & $x$ & & & $x$ & & $x$ & $x$ & $x$ & $x$ & $\mathrm{x}$ \\
\hline & & $x$ & $x$ & $x$ & $x$ & $x$ & $x$ & & & & & & & $x$ & $x$ & $x$ & \\
\hline & & $x$ & $x$ & $x$ & $x$ & $x$ & $x$ & & & & $x$ & & & & & & \\
\hline & \multirow{4}{*}{$\begin{array}{l}\text { Suženje } \\
\text { kolovoza } \\
\text { Veštačke } \\
\text { šikane } \\
\text { Smanjenje } \\
\text { radijusa ivičnog } \\
\text { zaobljenja } \\
\text { Reljefni } \\
\text { kolovozi }\end{array}$} & & & $x$ & & & & $x$ & $x$ & $x$ & $x$ & & & & & & \\
\hline & & $x$ & $x$ & $x$ & $x$ & $x$ & $x$ & $x$ & $x$ & $x$ & $x$ & $x$ & $x$ & & & $x$ & \\
\hline & & & & & & & & & & & & & & & & & \\
\hline & & $x$ & $x$ & $x$ & $x$ & $x$ & $x$ & $x$ & $x$ & $x$ & $x$ & $x$ & & & $x$ & $x$ & \\
\hline
\end{tabular}

Tabela 2. Kriterijumi za izbor tipa usporivača na dvosmernoj ulici

\begin{tabular}{|c|c|c|c|c|c|c|c|c|c|c|c|c|c|c|c|c|c|}
\hline & \multicolumn{3}{|c|}{$\begin{array}{l}\text { Profil ulice sa } \\
\text { trotoarom }\end{array}$} & \multicolumn{3}{|c|}{$\begin{array}{l}\text { Profil ulice bez } \\
\text { trotoara }\end{array}$} & \multicolumn{3}{|c|}{$\begin{array}{l}\text { Karakteristike } \\
\text { trase }\end{array}$} & \multicolumn{3}{|c|}{$\begin{array}{l}\text { Svrha } \\
\text { postavljanja }\end{array}$} & \multicolumn{4}{|c|}{$\begin{array}{l}\text { Karakteristike } \\
\text { saobraćajnog toka }\end{array}$} \\
\hline & & 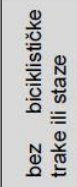 & 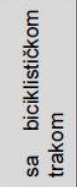 & 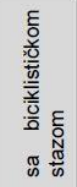 & 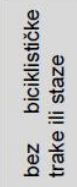 & 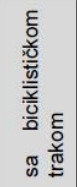 & 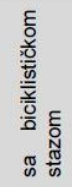 & 임 & 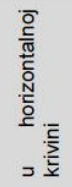 & 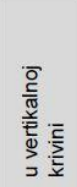 & 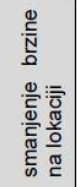 & 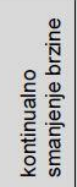 & 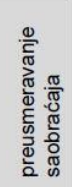 & 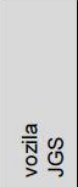 & 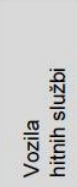 & 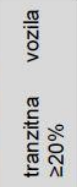 & 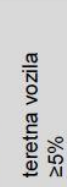 \\
\hline$\stackrel{\bar{U}}{\longleftarrow}$ & $\begin{array}{l}\text { Zvučne } \\
\text { trake }\end{array}$ & $x$ & $x$ & $x$ & $x$ & $x$ & $x$ & & & & $x$ & $x$ & & & & & \\
\hline 옹 & $\begin{array}{l}\text { Dragon } \\
\text { teeth }\end{array}$ & $x$ & $x$ & $x$ & $x$ & $x$ & $x$ & $x$ & & & $x$ & & & & & & \\
\hline 10 & $\begin{array}{l}\text { Obojeni } \\
\text { kolovoz }\end{array}$ & $x$ & $x$ & $x$ & $x$ & $x$ & $x$ & & & & & & & $x$ & $x$ & $x$ & $x$ \\
\hline & $\begin{array}{l}\text { Permanentne } \\
\text { veštačke izbočine } \\
\text { Veštačke izbočine } \\
\text { iz dva ili tri dela }\end{array}$ & & $x$ & $x$ & & $x$ & $x$ & $x$ & & & $x$ & & $x$ & & & $\mathrm{x}$ & \\
\hline & \multirow{2}{*}{$\begin{array}{l}\text { Veštačka } \\
\text { izbočina - jastuk } \\
\text { Gumeni } \\
\text { diskovi } \\
\text { Izdignute } \\
\text { Platforme }\end{array}$} & $x$ & $x$ & $x$ & $x$ & $x$ & $x$ & & & & & & & $x$ & $x$ & $x$ & \\
\hline & & $x$ & $x$ & $x$ & $x$ & $x$ & $x$ & & & & $x$ & & & & & & \\
\hline & \multirow{4}{*}{$\begin{array}{l}\text { Suženje } \\
\text { kolovoza } \\
\text { Veštačke } \\
\text { šikane } \\
\text { Smanjenje } \\
\text { radijusa ivičnog } \\
\text { zaobljenja } \\
\text { Reljefni } \\
\text { kolovozi }\end{array}$} & & & $x$ & & & & $x$ & $x$ & $x$ & $x$ & & & & & & \\
\hline & & & & $x$ & & & $x$ & $x$ & $x$ & $x$ & $x$ & $x$ & $x$ & & & $x$ & \\
\hline$\sum_{\substack{\alpha \\
0}}^{\substack{\alpha \\
0}}$ & & & & & & & & & & & & & & & & & \\
\hline 党 & & $x$ & $x$ & $x$ & $x$ & $x$ & $x$ & $x$ & $x$ & $x$ & $x$ & $x$ & & & $x$ & $x$ & \\
\hline
\end{tabular}


Tabela 3. Kriterijumi za izbor tipa usporivača na izdvojenom pešačkom prelazu

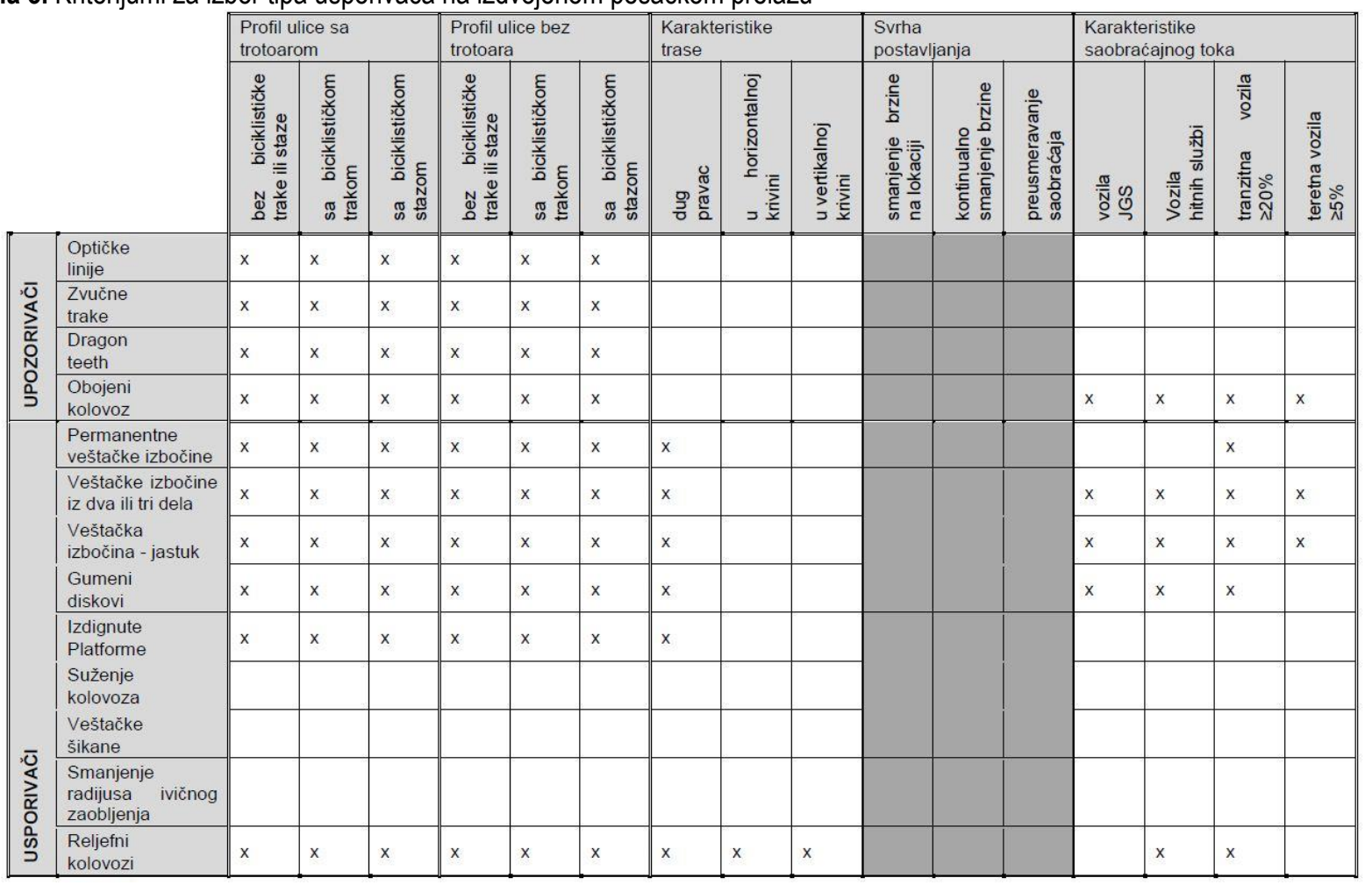

Tabela 4. Kriterijum za izbor tipa usporivača na raskrsnici

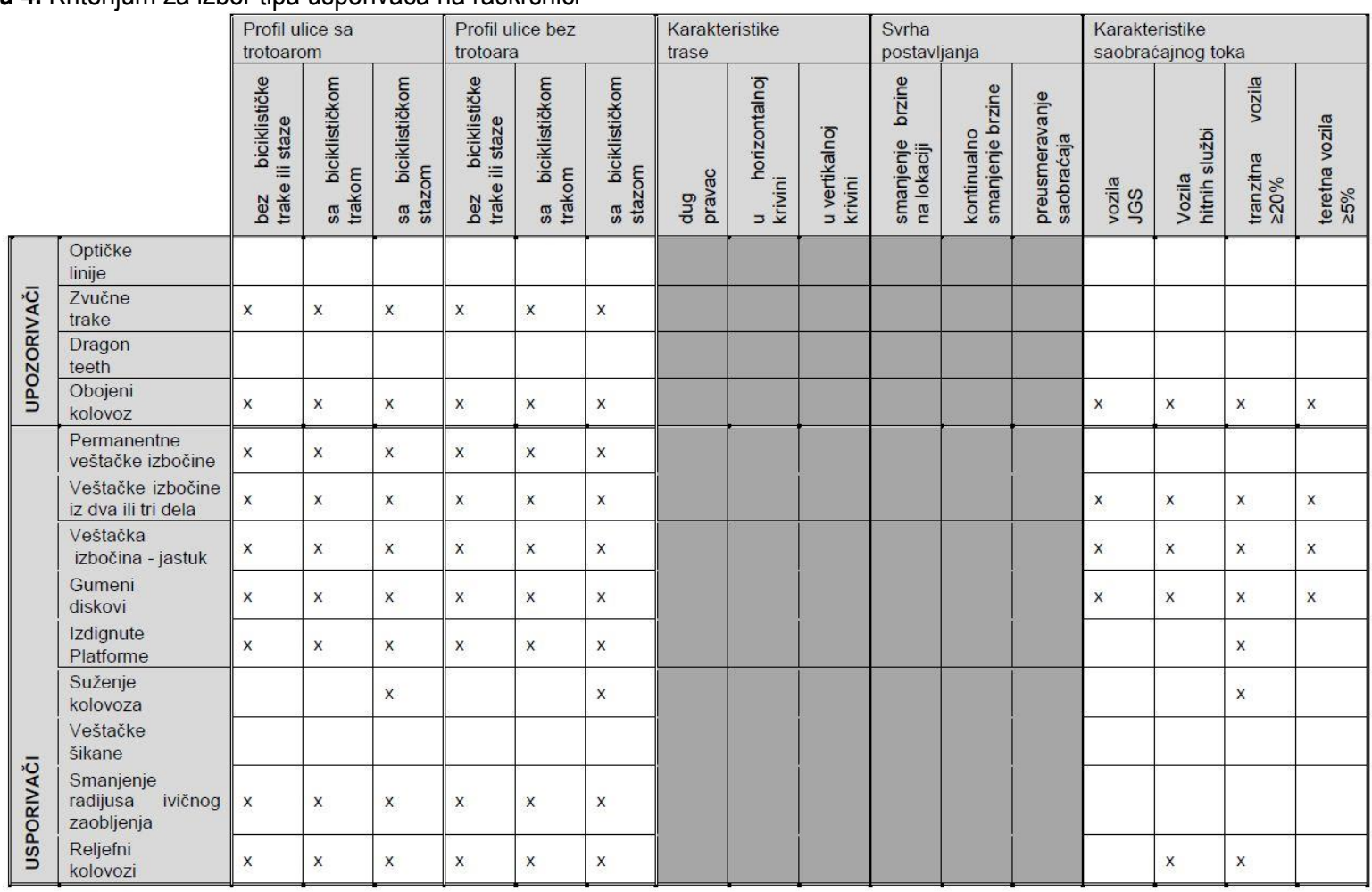


Tabela 5. Kriterijumi za vrednovanje pogodnosti lokacije za postavljanje fizičkih prepreka za usporavanje saobraćaja

\begin{tabular}{|l|c|c|c|}
\hline \multicolumn{1}{|c|}{ KRITERIJUM } & \multicolumn{3}{c|}{ BROJ BODOVA } \\
\hline 1. Udaljenost od rizičnih lokacija & $<100 \mathrm{~m}$ & $100-200 \mathrm{~m}$ & $200-300 \mathrm{~m}$ \\
\hline Predškolska ustanova & 10 & 5 & 3 \\
\hline Osnovna škola & 10 & 5 & 3 \\
\hline Srednja škola & 8 & 4 & 2 \\
\hline Dečije igralište & 5 & 2 & 1 \\
\hline $\begin{array}{l}\text { 2. Broj saobraćajnih nezgoda u } \\
\text { prethodnih 5 godina u zoni od 100 m }\end{array}$ & $>5$ & $3-5$ & $<3$ \\
\hline SN sa metrijalnom štetom & 4 & 2 & 1 \\
\hline SN sa povređenima & 8 & 4 & 3 \\
\hline SN sa poginulima & 10 & 8 & 5 \\
\hline 3. Vrednost PGDS [voz/dan] & $\leq 200$ & $200-5000$ & $\geq 5000$ \\
\hline & 0 & 5 & 0 \\
\hline 4. Smernost ulice & jednosmerna & & dvosmerna \\
\hline & 3 & & 5 \\
\hline 5. Procenat prekoračenja brzine & $>50 \%$ & $30-50 \%$ & $<30 \%$ \\
\hline & 10 & 5 & 3 \\
\hline 6. Dužina neprekidnog pravca & $>300 \mathrm{~m}$ & $100-300 \mathrm{~m}$ & $<100 \mathrm{~m}$ \\
\hline & 5 & 3 & 1 \\
\hline 7. Postojanje trotoara & bez trotoara & jednostrano & dvostrano \\
\hline & 5 & 2 & 0 \\
\hline $\begin{array}{l}\text { 8. Učešće tranzitnih tokova u } \\
\text { saobraćajnom toku }\end{array}$ & $\leq 10 \%$ & $10-20 \%$ & $\geq 20 \%$ \\
\hline & 0 & 3 & 5 \\
\hline $\begin{array}{l}\text { 9. Broj prelazaka kolovoza od strane } \\
\text { pešaka [pešaka/h] }\end{array}$ & $>500$ & $100-500$ & $<100$ \\
\hline & 5 & 2 & 0 \\
\hline 10. Ulično parkiranje duž kolovoza & Da & & Ne \\
\hline & 5 & & 0 \\
\hline UKUPNO: 1+2+3+4+5+6+7+8+9+10 & & najviše 100 bodova \\
\hline
\end{tabular}

\section{ZAKLJUČAK}

Ugradnja usporivača je jedna od najstarijih i najčešće korišćenih mera za smanjenje i kontrolu brzine na putevima i ulicama koja se primenjuje $u$ čitavom svetu. Zbog pozitivnih efekata koji se postižu ugradnjom usporivača, u mnogim urbanim sredinama zahtevi građana za postavljanjem usporivača postali su sve češći. Zbog toga se pojavila potreba, odnosno razlozi, za dodatnim regulisanjem ove oblasti od strane lokalne zajednice, koja je upravljač lokalnom putnom i uličnom mrežom. Iz tog razloga su mnogi gradovi, pokrajine ili regije propisale procedure i kriterijume za postavljanje usporivača. $U$ našoj zemlji do donošenje „Zakona o bezbednosti saobraćaja na putevima“ 2009. godine nije postojala zakonska regulativa vezana za usporivače. Tek 2014. godine donet je „Pravilnik o tehničkim sredstvima za usporavanje saobraćaja na putu“ koji je stupio na snagu početkom 2014. godine. Donošenjem ovih pravnih akata praktično je omogućeno i lokalnim zajednicama da u okviru svojih nadležnosti definišu i bliže urede oblast primene usporivača na putnoj uličnoj mreži za koju su oni kao upravljači nadležni.

U ovom radu razmatrana su svetska iskustva, procedure, pravilnici, preporuke i kriterijumi za postavljanje usporivača u gradovima sveta. Nakon detaljnih analiza dat je predlog kriterijuma za Grad Novi Sad, u okviru kojih je definisana procedura pokretanja inicijative za ugradnju usporivača, kriterijumi za izbor delova ulične mreže na kojima je moguće postavljati usporivače, kriterijumi za izbor vrste usporivača u skladu sa karakteristikama lokacije, kriterijumi za izbor mirkolokacije u okviru izabrane lokacije, kao i postupak vrednovanja i kvalifikovanja lokacija za ugradnju usporivača.

\section{Literatura}

[1] Bellefleur, O., Gagnon, F. (2011). Urban traffic calming and health literature review, National Collaborating Centre for Healthy Public Policy

[2] FHWA (2010). Traffic Calming: Course on Bicycle and Pedestrian Transportation

[3] Bogdanović, V. et al. (2017). "Primena prinudnih usporivača saobraćaja na teritoriji Grada Novog Sada sa posebnim osvrtom na metodologiju i uslove za implementaciju mera", Fakultet tehničkih nauka, Novi Sad

[4] Citizens Handbook for Requesting Traffic Calming Devices (2015). City of Sachse, USA

[5] Main Streets: Flexibility in Design \& Operations (2005). Caltrans California Department of Transportation.

[6] Residential Traffic Calming Program: Policies, procedures and resources (2007). State of California, The City of San Ramon, USA

[7] Residential Traffic Calming Handbook: How to calm excessive traffic and speeding in residential areas (2007). The City of Deltona, Florida, USA

[8] Reid, E. (1999). Traffic Calming: State of the Practice, Institute of Transportation Engineers (ITE)

[9] FHWA (2001). The Effects of Traffic Calming Measures on Pedestrian and Motorist Behavior, REPORT NO. FHWA-RD-00-104

[10] Traffic Calming and System Management (2005). DDOT - District Department of Transportation, USA

[11] The Highways (Road Humps) Regulations (1999) 